\title{
Naphthoquinone and Triazoles With Dual Action to Combat Infectious Disease with A Prominent Inflammatory Response
}

\author{
Pacheco PAF and Faria RX* \\ Laboratório de Toxoplasmose e outras Protozoozes, Pavilhão Carlos Chagas, Instituto Oswaldo Cruz, Avenida Brasil, 4365, Rio \\ de Janeiro, Brazil
}

*Corresponding author: Faria RX, Laboratório de Toxoplasmose e outras Protozoozes, Pavilhão Carlos Chagas, Instituto Oswaldo Cruz, Avenida Brasil, 4365, Rio de Janeiro, Brazil

\begin{tabular}{|c|c|}
\hline ARTICLE INFO & ABSTRACT \\
\hline Received: 豐September 26, 2020 & Citation: Pacheco PAF, Faria RX. Naphthoquinone and Triazoles With Dual Action to \\
\hline Published: & $\begin{array}{l}\text { Combat Infectious Disease with A Prominent Inflammatory Response. Biomed J Sci \& } \\
\text { Tech Res 30(5)-2020. BJSTR. MS.ID.005026. }\end{array}$ \\
\hline
\end{tabular}

\section{Short Communication}

Chagas disease, also attributed to American trypanosomiasis, is an anthropozoonosis caused by the parasite Trypanosoma cruzi and transmitted by insect triatomine vectors [1]. This disease is considered endemic in 21 countries in Central and South America, consisting of a severe public health problem [2]. Regarding the clinical course, Chagas disease has two phases: an acute phase, characterized by high parasitemia, and a chronic phase that persists throughout the individual's life. In most cases, the acute phase is asymptomatic or oligosymptomatic with fever, inflammation at the inoculation site (inoculation chagoma), unilateral eyelid edema (Romaña sign), lymphadenopathy, and hepatosplenomegaly [3]. These manifestations spontaneously disappear in most infected individuals, even without drug intervention, and the disease progresses to the chronic phase. Approximately $60-70 \%$ of patients develop the chronic indeterminate form of the disease, characterized by the absence of clinical manifestations. The remaining $30-40 \%$ of patients who develop the disease have a chronic form 10-30 years after the initial infection.

This phase is characterized by neurological, cardiovascular, digestive system, or cardiodigestive impairment [3]. Currently, the treatment for Chagas disease is based only on two nitroheterocyclic compounds, benznidazole (1) and nifurtimox (2) (Figure 1). However, both substances present several drawbacks: they are more effective in the initial stages of infection against trypomastigote and amastigote forms, require long treatment times, exhibit high toxicity in adults, and present different susceptibility profiles concerning the different strains of T. cruzi. In this sense, there is an immediate need to develop new trypanocidal drugs that are more effective and have an acceptable good safety profile [4]. In the development of Chagas disease, a high inflammatory response is present both in the acute and chronic phases. Particularly in patients with a determined chronic form, there is evidence that an uncontrolled inflammatory response contributes to the disease's pathogenesis. Among the different membrane receptors that modulate the inflammatory response, purinergic receptors can be promising molecular targets due to the evidence of receptors sensitive to extracellular ATP in the membrane of trypomastigote forms and the upregulation of ectonucleotidase activity in murine cells infected with T. cruzi [5-7]. 
<smiles>O=C(Cn1ccnc1[N+](=O)[O-])NCc1ccccc1</smiles>

(1)<smiles>CC1CS(=O)(=O)CCN1/N=C/c1ccc([N+](=O)[O-])o1</smiles>

(2)

Figure 1: Structure of benzonidazole (1) and nifurtimox (2).

A vast number of natural substances have been continuously studied to search for a safer and more effective treatment for Chagas disease [8]. Naphthoquinones represent a promising class of natural products with trypanocidal activity [9]. Several natural and synthetic naphthoquinones have been evaluated against different developmental forms of T. cruzi [10-12]. In this context, naphthoquinones have served as useful synthetic platforms to obtain more selective and potent compounds. The addition of the nitrogen heterocycle 1,2,3-triazole has proven to be a promising chemical strategy to generate bioactive naphthoquinone derivatives [13-16]. Our research group has recently shown that different naphthoquinone derivatives have also exhibited potential inhibitory activity towards the P2X7 receptor, a subtype of purinergic receptors directly related to inflammatory responses [17].
Interestingly, we have also identified two triazoyl-naphthoquinone derivatives (Figure 2) with potent antagonist activity towards P2X7R [18]. Despite its fundamental role in inflammatory responses, to date, there are no studies that directly correlate P2X7R activity with the inflammatory dysregulation observed in patients with Chagas disease. Considering the pharmacological activities of naphthoquinone and triazole nuclei independently, we believe that this association can provide new compounds with immunomodulatory activity that may exert beneficial effects through P2X7R inhibition and direct trypanocidal action. However, we perceived that more studies are needed to identify the real relevance of P2X7R-mediated signaling pathways in Chagas disease pathogenesis, particularly in patients with chronic determinate infection.

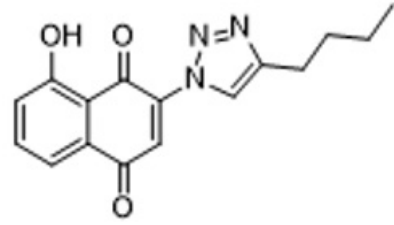

(3)

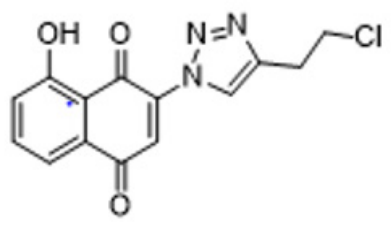

(4)

Figure 2: Structure of triazoyl-naphthoquinone derivatives with P2X7R inhibitory activity.

\section{References}

1. Rassi A, Rassi A, Marcondes de Rezende (2012) American Trypanosomiasis (Chagas Disease) Infectious Disease Clinics of North America 26(2): 275-291.

2. Nunes MCP, Dones W, Morillo CA, Encina JJ, Ribeiro AL (2013) Chagas disease: An overview of clinical and epidemiological aspects. J Am Coll Cardiol 62(9): 767-776.

3. Rassi A, de Rezende JM, Luquetti AO, Rassi A (2017) Clinical phases and forms of Chagas disease. In: American Trypanosomiasis Chagas Disease: One Hundred Years of Research ( $2^{\text {nd }}$ Edn.) pp. 653-686.

4. Bermudez J, Davies C, Simonazzi A, Pablo Real J, Palma S (2016) Current drug therapy and pharmaceutical challenges for Chagas disease. National library of Medicine 156: 1-16.

5. Talvani A, Teixeira MM (2011) Inflammation and chagas disease: Some mechanisms and relevance. In: Advances in Parasitology pp. 171-194.

6. Inverso JA, Song Y, Santos Buch CA (1995) Plasma membrane ATP receptors in Trypanosoma cruzi trypomastigotes. Receptor 5(4): 197 206.
7. Do Carmo GM, Doleski PH, de Sá MF, Grando TH, Bottari NB, et al. (2017) Purinergic ecto-enzymes participate in the thromboregulation in acute in mice infection by Trypanosoma cruzi. Mol Cell Biochem 432(1-2).

8. Izumi E, Ueda Nakamura T, Dias Filho BP, Veiga Júnior VF, Nakamura CV (2011) Natural products and Chagas disease: A review of plant compounds studied for activity against Trypanosoma cruzi. Nat Prod Rep 28(4): 809-823.

9. Salas C, Faundez M, Morello A, Diego Maya J, Tapia R (2010) Natural and Synthetic Naphthoquinones Active Against Trypanosoma Cruzi: An Initial Step Towards New Drugs for Chagas Disease. Curr Med Chem 18(1): 144-161.

10. Lopes JN, Cruz FS, Docampo R, Vasconcellos ME, Vasconcellos $\mathrm{ME}$, et al. (1978) In vitro and in vivo evaluation of the toxicity of 1 , 4-naphthoquinone and 1, 2-naphthoquinone derivatives against Trypanosoma cruzi. Ann Trop Med Parasitol 72(6): 523-531.

11. Menna Barreto RFS, Goncalves RLS, Costa EM, Silva RSF, Pinto AV, et al. (2009) The effects on Trypanosoma cruzi of novel synthetic naphthoquinones are mediated by mitochondrial dysfunction. Free Radic Biol Med 47(5): 644-653. 
12. Carneiro PF Do Nascimento SB, Pinto AV, Pinto MDCFR, Lechuga GC, Santos DO, et al. (2012) New oxirane derivatives of 1,4-naphthoquinones and their evaluation against T. cruzi epimastigote forms. Bioorganic Med Chem 20(16): 4995-5000.

13. da Silva EN, Menna Barreto RFS, Pinto M do CFR, Silva RSF, Teixeira DV, et al. (2008) Naphthoquinoidal [1,2,3]-triazole, a new structural moiety active against Trypanosoma cruzi. Eur J Med Chem 43(8): 1774-1780.

14. Da Silva EN, De Melo IMM, Diogo EBT, Costa VA, De Souza Filho JD, et al. (2012) On the search for potential anti-Trypanosoma cruzi drugs: Synthesis and biological evaluation of 2-hydroxy-3-methylamino and 1,2,3-triazolic naphthoquinoidal compounds obtained by click chemistry reactions. Eur J Med Chem 52: 304-312.

15. Diogo EBT, Dias GG, Rodrigues BL, Guimarães TT, Valença WO, et al. (2013) Synthesis and anti-Trypanosoma cruzi activity of naphthoquinone-

\section{ISSN: 2574-1241}

DOI: $10.26717 / B J S T R .2020 .30 .005026$

Faria RX. Biomed J Sci \& Tech Res

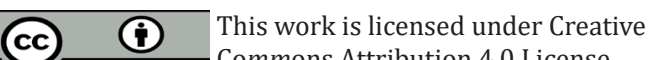

Submission Link: https://biomedres.us/submit-manuscript.php containing triazoles: Electrochemical studies on the effects of the quinoidal moiety. Bioorganic Med Chem 21(21): 6337-6348.

16. Pinto AV, Pinto M do CFR, de Souza MCBV, Araújo AJ (2009) Cytotoxic, trypanocidal activities and physicochemical parameters of nor- $\beta$ lapachone-based 1,2,3-triazoles. J Braz Chem Soc 20(4): 635-643.

17. Faria RX, Oliveira FH, Salles JP, Oliveira AS (2018) 1,4-Naphthoquinones potently inhibiting P2X7 receptor activity. Eur J Med Chem 143: 13611372 .

18. Pacheco PAF, Galvão RMS, Faria AFM, Von Ranke NL, Rangel MS, et al. (2019) 8-Hydroxy-2-(1H-1,2,3-triazol-1-yl)-1,4-naphtoquinone derivatives inhibited P2X7 Receptor-Induced dye uptake into murine Macrophages. Bioorganic Med Chem 27(8): 1449-1455.

$\begin{array}{ll}\text { BIOMEDICAL } & \text { Assets of Publishing with us } \\ \text { RESEARCHES } & \text { Global archiving of articles } \\ \text { - Immediate, unrestricted online access } & \text { - Rigorous Peer Review Process } \\ & \text { - Authors Retain Copyrights } \\ & \end{array}$

